\title{
Providencia friedericiana, a New Species Isolated from Penguins
}

\author{
H. E. MÜLLER \\ Staatliches Medizinaluntersuchungsamt, D-3300 Braunschweig, West Germany
}

\begin{abstract}
The name Providencia friedericiana sp. nov. is proposed for a well-defined group of organisms that were isolated from fecal specimens from penguins (Aptenodytes patagonica, Eudyptes crestatus, Pyoscelis papua, Spheniscus demersus, and Spheniscus humboldti). P. friedericiana strains are gram-negative, oxidase-negative, fermentative rods that grow on Endo agar, MacConkey agar, Wilson-Blair agar, and some other selective media for Enterobacteriaceae. They are acetate, adonitol, arginine dihydrolase, gelatinase, inositol, lactose, lysine decarboxylase, mannitol, ornithine decarboxylase, tartrate, trehalose, urease, and Voges-Proskauer negative, but fructose, galactose, glucose, glycerol, indole, catalase, $\mathrm{KCN}$, nitrate reductase, mannose, methyl red, and phenylalanine deaminase positive. Simmons citrate is utilized weakly and variably. Gas is produced from glucose in small amounts or not at all. The organisms possess flagella when they are grown at $25^{\circ} \mathrm{C}$. They show moderate motility at $25^{\circ} \mathrm{C}$ but are nonmotile or only slightly motile at $36^{\circ} \mathrm{C}$. Capsules and slime layers are not produced. The type strain of $P$. friedericiana, strain $1 / 33$, has been deposited with the Deutsche Sammlung von Mikroorganismen as strain DSM 2620.
\end{abstract}

The genus Providencia, which was described by Ewing in 1962, contains three species, Providencia alcalifaciens, Providencia rettgeri, and Providencia stuartii, which are included on the Approved Lists of Bacterial Names (17). From fecal specimens of penguins a well-defined group of bacteria that were distinguishable by their morphological and biochemical characteristics were isolated on media that are used for isolation of Enterobacteriaceae.

In this paper I describe the properties of 206 isolates belonging to 61 strains which resemble the members of the genus Providencia, yet differ from the three previously described species. This group most closely resembles $P$. alcalifaciens but differs from this species in producing negative acetate, adonitol, and tartrate reactions. Furthermore, citrate utilization, motility at $36^{\circ} \mathrm{C}$, and gas production from glucose are weak or do not occur. Positive glycerol and sucrose reactions are delayed. There is evidence that these isolates constitute a new species. In this paper this new species is described, characterized, and classified. The name Providencia friedericiana sp. nov. is proposed for this organism.

\section{MATERIALS AND METHODS}

Source. A total of 206 isolates were obtained from feces of five different penguin species living in the zoological gardens of Duisburg, Frankfurt, Gelsenkirchen, Hamburg, Hannover, Cologne, Munich, and
Stuttgart, West Germany. Fecal samples from penguins from some other zoological gardens did not contain $P$. friedericiana isolates (Table 1).

Isolation. The fecal specimens were cultured on Endo agar, MacConkey agar, salmonella-shigella agar, and xylose-lysine-deoxycholate agar. Enrichment cultures in selenite and tetrathionate broth media were subcultured on these four plating media after overnight incubation at $36^{\circ} \mathrm{C}$. Colonies of the new species formed on all media. Each colony that was different from the others was picked out and tested. A total of 61 strains were represented in the 206 isolates.

The following media and reagents were used for screening: indophenol-oxidase test medium, Kligler agar, lysine-indole motility medium (3), ornithineindole motility medium (18), malonate-phenylalanine medium, Christensen urea agar, and Simmons citrate agar $(8,13)$.

Strains. Strains with typical reactions were studied by using additonal biochemical tests. Type strains $P$. alcalifaciens ATCC 9886, P. stuartii (ATCC 25825, and Proteus rettgeri DSM 1131 (= NCTC 7481) were included for comparison.

Morphology. Colonial morphology and hemolysis of blood were determined on blood agar plates (blood agar base no. 2; Oxoid) containing 5\% defibrinated sheep blood. The plates were incubated for 18 to $24 \mathrm{~h}$ at $36 \pm 1{ }^{\circ} \mathrm{C}$. Gram stains were performed by using 18 to 24-h cultures, as described elsewhere (11). Flagellar morphology was determined by the Forbes method (9) for 10 strains. For flagellum staining the bacteria were incubated on semisolid motility medium at 25 or $36^{\circ} \mathrm{C}$ for 18 to $48 \mathrm{~h}$. The occurrence of a capsule was tested by the Duguid-Hiss method (10).

Biochemical tests. The biochemical tests were performed by using standard procedures $(6,8,11,13)$. 
TABLE 1. P. friedericiana isolates obtained from penguins

\begin{tabular}{|c|c|c|}
\hline \multirow[b]{2}{*}{ Laboratory isolate(s) } & \multicolumn{2}{|c|}{ Isolated from: } \\
\hline & $\begin{array}{l}\text { Animal } \\
\text { no. }\end{array}$ & Species \\
\hline $\begin{array}{l}1 / 1,^{a} 1 / 2,1 / 3,1 / 4,1 / 6,{ }^{a} 1 / 7,1 / 8,1 / 9,1 / 10,1 / 11 \\
1 / 12,1 / 13,1 / 15\end{array}$ & $1 \mathrm{~A}$ & Aptenodytes patagonica \\
\hline $1 / 16,^{a} 1 / 17$ & $2 \mathrm{~A}$ & Spheniscus humboldti \\
\hline $1 / 18,^{a} 1 / 19,{ }^{a} 1 / 20,^{a} 1 / 21$ & $6 \mathrm{~A}$ & Spheniscus demersus \\
\hline $\begin{array}{l}1 / 22,{ }^{a} 1 / 23,1 / 24,{ }^{a} 1 / 25,1 / 26,1 / 27,1 / 28,1 / 29 \\
\quad 1 / 30,1 / 31\end{array}$ & $8 \mathrm{~A}$ & Aptenodytes patagonica \\
\hline $\begin{array}{r}1 / 32,{ }^{a} 1 / 33,{ }^{a} 1 / 34,^{a} 1 / 35,1 / 36,1 / 37,1 / 38,1 / 39 \\
1 / 40,1 / 41,{ }^{a} 1 / 42,1 / 43,1 / 44,1 / 45,1 / 46,1 / 47\end{array}$ & $10 \mathrm{~A}$ & Pyoscelis papua \\
\hline $1 / 48,{ }^{a} 1 / 49,1 / 50,1 / 51,1 / 52,1 / 53,1 / 54$ & $12 \mathrm{~A}$ & Aptenodytes patagonica \\
\hline $\begin{array}{l}1 / 55,{ }^{a} 1 / 56,{ }^{a} 1 / 57,1 / 58,1 / 59,1 / 60,1 / 61,1 / 62 \\
1 / 63,{ }^{a} 1 / 64,{ }^{a} 1 / 65,{ }^{a} 1 / 66,{ }^{a} 1 / 67,1 / 68,1 / 69,1 / 70 \\
1 / 71,1 / 72,1 / 73,1 / 74\end{array}$ & $14 \mathrm{~A}$ & Pyoscelis papua \\
\hline $\begin{array}{l}1 / 75,,^{a} 1 / 76,^{a} 1 / 77,1 / 78,{ }^{a} 1 / 79,1 / 80,1 / 81,{ }^{a} 1 / 82 \\
1 / 83,1 / 84\end{array}$ & $15 \mathrm{~A}$ & Pyoscelis papua \\
\hline $\begin{array}{l}1 / 86,^{a} 1 / 87,1 / 88,1 / 90,1 / 93,1 / 94,1 / 95,1 / 96 \\
1 / 97,1 / 98\end{array}$ & $16 \mathrm{~A}$ & Eudyptes crestatus \\
\hline $1 / 99,{ }^{a} 1 / 100,1 / 101$ & $17 \mathrm{~A}$ & Spheniscus humboldti \\
\hline $\begin{array}{l}1 / 102,{ }^{a} 1 / 103,1 / 106,1 / 111,{ }^{a} 1 / 112,1 / 113,1 / 114, \\
1 / 115,1 / 116,1 / 117,1 / 118\end{array}$ & $18 \mathrm{~A}$ & Aptenodytes patagonica \\
\hline $\begin{array}{l}1 / 119,{ }^{a} 1 / 120,^{a} 1 / 121,1 / 122,{ }^{a} 1 / 123,{ }^{a} 1 / 124 \\
1 / 125,1 / 126,1 / 127,1 / 128,{ }^{a} 1 / 129,1 / 130,1 / 131 \\
1 / 132,1 / 133^{a}\end{array}$ & $19 \mathrm{~A}$ & Aptenodytes patagonica \\
\hline $1 / 134,^{a} 1 / 135,^{a} 1 / 136,1 / 137^{a}$ & $28 \mathrm{~A}$ & Spheniscus humboldti \\
\hline $1 / 138,{ }^{a} 1 / 139,^{a} 1 / 140,1 / 141^{a}$ & $31 \mathrm{~A}$ & Spheniscus demersus \\
\hline $1 / 142,{ }^{a} 1 / 147^{a}$ & $32 \mathrm{~A}$ & Spheniscus demersus \\
\hline $1 / 149^{a}$ & $33 \mathrm{~A}$ & Spheniscus demersus \\
\hline $1 / 150,^{a} 1 / 151,1 / 152,1 / 153^{a}$ & $35 \mathrm{~A}$ & Aptenodytes patagonica \\
\hline $\begin{array}{l}1 / 143,{ }^{a} 1 / 144,{ }^{a} 1 / 145,{ }^{a} 1 / 146,1 / 154,{ }^{a} 1 / 155 \\
1 / 156,1 / 157,1 / 158,1 / 159\end{array}$ & $36 \mathrm{~A}$ & Aptenodytes patagonica \\
\hline $\begin{array}{l}2 / 110,{ }^{a} 2 / 155,{ }^{a} 2 / 159,{ }^{a} 2 / 195,2 / 196,2 / 202,2 / 203 \\
\quad 2 / 204\end{array}$ & $9 \mathrm{~B}$ & Aptenodytes patagonica \\
\hline $\begin{array}{l}2 / 166,{ }^{a} 2 / 213,2 / 219,2 / 221,2 / 223,2 / 224,2 / 225 \\
\quad 2 / 226,2 / 227\end{array}$ & $14 B$ & Aptenodytes patagonica \\
\hline $\begin{array}{l}2 / 181,{ }^{a} 2 / 238,{ }^{a} 2 / 240,2 / 241,2 / 242,2 / 263,{ }^{a} 2 / 264 \\
2 / 318,{ }^{a} 2 / 327,{ }^{a} 2 / 329,2 / 330,2 / 331,2 / 332 \\
2 / 335,2 / 337,2 / 341,2 / 342\end{array}$ & 28B & Pyoscelis papua \\
\hline $\begin{array}{l}2 / 343,{ }^{a} 2 / 344,2 / 355,2 / 372,{ }^{a} 2 / 373,2 / 375,2 / 376 \\
\quad 2 / 378,2 / 379,2 / 380,2 / 382,2 / 383\end{array}$ & $30 \mathrm{~B}$ & Eudyptes crestatus \\
\hline $\begin{array}{l}2 / 385,^{a} 2 / 386,2 / 387,2 / 388,2 / 392,2 / 396,2 / 400 \\
2 / 402,2 / 403,2 / 405,{ }^{a} 2 / 406,2 / 407,2 / 409,2 / 412\end{array}$ & $31 \mathrm{~B}$ & Spheniscus humboldti \\
\hline
\end{tabular}

${ }^{a}$ Different strains from individual animals.

Pigment production. Pigment production was assayed on a nutrient agar containing $8 \mathrm{~g}$ of tyrosine per liter and $0.25 \mathrm{~g}$ of soluble ferric pyrophosphate per liter under aerobic conditions.

Guanine-plus-cytosine content. The guanine-plus-cytosine content of deoxyribonucleic acid was determined optically by thermal denaturation (R. Hammann, personal communication).

Antimicrobial agent susceptibility tests. Antibiograms were done on Mueller-Hinton agar by the disk method, as described by Bauer et al. (2). Zone sizes were designated as susceptible, intermediate, or resistant according to the recommendations of the DIN 58940 method (7).

\section{RESULTS}

Morphology. $P$. friedericiana cells were gramnegative, nonsporeforming, and rod shaped (about 0.5 by 1.0 to $3.0 \mu \mathrm{m}$ ). The organisms grown at $25^{\circ} \mathrm{C}$ showed many peritrichously flagellated forms with five to eight flagella. However, when strains were grown at $36^{\circ} \mathrm{C}$, they produced no or only a few flagellated cells; the flagellar morphology was poor, and the number of flagella was one or two. Capsules of slime layers were not detected.

Growth on media. Colonies of $\boldsymbol{P}$. friedericiana grown overnight on blood agar plates at $36^{\circ} \mathrm{C}$ were about 1.0 to $2.0 \mathrm{~mm}$ in diameter, glossy, semitranslucent, and smooth. Hemolysis did not occur. The strains grew poorly at 4 and $44^{\circ} \mathrm{C}$, moderately between 10 and $22^{\circ} \mathrm{C}$, and well at 30 , 36 , and $40^{\circ} \mathrm{C}$. There was also good growth on differential plating media that are selective for Enterobacteriaceae, with some exceptions (Ta- 
TABLE 2. Growth and appearance of $19 P$. friedericiana strains on selective plating media

\begin{tabular}{|c|c|c|c|c|c|c|c|c|c|c|}
\hline \multirow[t]{2}{*}{ Agar } & \multicolumn{2}{|c|}{ Appearance of colonies after: } & \multicolumn{4}{|c|}{$\begin{array}{c}\text { Growth of } 19 \text { strains after } 1 \\
\text { day }\end{array}$} & \multicolumn{4}{|c|}{$\begin{array}{c}\text { Growth of } 19 \text { strains after } 2 \\
\text { days }\end{array}$} \\
\hline & 1 day & 2 days & None & Poor & Medium & Good & None & Poor & Medium & Good \\
\hline Brilliant green & Colorless & Greenish & $1^{a}$ & 18 & & & & 15 & 4 & \\
\hline Cetrimide & Colorless & Colorless & 14 & 5 & & & 7 & 12 & & \\
\hline Endo & Pink & Red & & & 19 & & & & 19 & \\
\hline $\begin{array}{l}\text { Eosine-methylene } \\
\text { blue }\end{array}$ & Colorless & Pink & & & 3 & 16 & & & 1 & 18 \\
\hline Hektoen & $\begin{array}{l}\text { Green, orange, } \\
\text { yellow }\end{array}$ & $\begin{array}{l}\text { Green, orange, } \\
\text { yellow }\end{array}$ & & & & 19 & & & & 19 \\
\hline Leifson & Colorless & Yellow, brown & & 1 & 3 & 15 & & & 1 & 18 \\
\hline MacConkey & Orange, red & Orange, red & & & & 19 & & & & 19 \\
\hline $\begin{array}{l}\text { Salmonella-shigel- } \\
\text { la }\end{array}$ & Colorless & Red, brown & 3 & 16 & & & & 17 & 2 & \\
\hline $\begin{array}{l}\text { Thiosulfate-ci- } \\
\text { trate-bile salt } \\
\text { sucrose }\end{array}$ & Yellow & Yellow, green & & & & 19 & & & & 19 \\
\hline Wilson-Blair & Yellow, green & Green, brown & & & 19 & & & & 3 & 16 \\
\hline $\begin{array}{l}\text { Xylose-lysine de- } \\
\text { oxycholate }\end{array}$ & Yellow, pink & Yellow, pink & & & 13 & 6 & & & 3 & 16 \\
\hline
\end{tabular}

${ }^{a}$ Number of strains.

ble 2). P. friedericiana produced a brownish pigment like other Providencia species and some Legionella species (1). Previously, Buttiaux, et al. noted that this pigmentation is produced only by members of the genus Providencia (5).

Biochemical reactions and description of $P$. friedericiana. The results of biochemical tests for $61 P$. friedericiana strains and type strain $1 / 33$ (= DSM 2620) are shown in Table 3. All strains were oxidase negative and catalase positive and reduced nitrate to nitrite; they showed the characteristics of the Enterobacteriaceae. Furthermore, these strains were negative in tests for arginine dihydrolase, lysine decarboxylase, and ornithine decarboxylase and positive for phenylalanine deaminase. They did not produce $\mathrm{H}_{2} \mathrm{~S}$, hydrolyze urea, or utilize malonate. The strains gave weak reactions for Simmons citrate utilization. They produced indole after growth in tryptone broth, but the production of indole in lysine-indole motility medium or ornithine-indole motility medium was very weak. About one-half of the strains were nonmotile at $36^{\circ} \mathrm{C}$; the others showed insignificant motility. Most strains were moderately motile at $25^{\circ} \mathrm{C}$, as determined in semisolid motility medium containing 2,3,5-triphenyltetrazolium chloride. $P$. friedericiana fermented glucose with the production of acid; gas was produced, but only in small amounts (often about a pinhead-sized gas bubble in Durham tubes) by most strains. All strains fermented galactose, fructose, and mannose after $24 \mathrm{~h}$ and glycerol and sucrose after 48 $\mathrm{h}$, but not adonitol, inositol, lactose, maltose, mannitol, trehalose, xylose, or some other carbohydrates. They gave negative Voges-Pros- kauer reactions and were positive in the methyl red test. Tyrosine clearing was positive. These organisms did not utilize acetate or Jordan tartrate.

Differentiation of $P$. friedericiana from other Providencia species. The uniform biochemical profile of the new group (Table 3 ) and its circumscribed habitat justify the proposition of a new species. This organism belongs to the family Enterobacteriaceae and to the genus Providencia. Table 4 shows tests that are useful in identifying $P$. friedericiana. This species is distinguishable from $P$. alcalifaciens by its regular negative reactions for acetate, adonitol, and tartrate, by its weak positive reactions for Simmons citrate utilization, by being nonmotile or very weakly motile at $36^{\circ} \mathrm{C}$, by no gas production or weak gas production from glucose, and by its obligately delayed positive reactions for glycerol and sucrose. In individual cases, however, differentiation between $P$. friedericiana and $P$. alcalifaciens may be difficult.

The description of $P$. alcalifaciens by Edwards and Ewing was based on an investigation of 633 strains (8). Of these strains, $83.9 \%$ belonged to biogroup $1,10.9 \%$ belonged to biogroup $2,2.5 \%$ belonged to biogroup 3 , and $2.7 \%$ belonged to biogroup 4 . The members of biogroups 3 and 4 did not ferment either adonitol or inositol. Therefore, $5 \%$ of these $P$. alcalifaciens strains resemble $P$. friedericiana more or less. Unfortunately, Edwards and Ewing did not describe the distribution of other biochemical reactions in the four biogroups, with the exception of gas production and fermentation of adonitol and inositol. Tartrate utilization is the single differ- 
TABLE 3. Biochemical reactions of $P$. friedericiana strains and the type strain

\begin{tabular}{|c|c|c|c|c|}
\hline \multirow{2}{*}{ Test } & \multirow{2}{*}{$\begin{array}{l}\text { No. of } \\
\text { strains } \\
\text { tested }\end{array}$} & \multicolumn{2}{|c|}{$\begin{array}{c}\text { Cumulative } \% \text { of strains positive } \\
\text { after: }\end{array}$} & \multirow{2}{*}{$\begin{array}{c}\text { Reaction of } \\
\text { type strain } \\
1 / 33(=\text { DSM } \\
2620)\end{array}$} \\
\hline & & 1 to 2 days & 3 to 7 days & \\
\hline Acetate utilization & 61 & 0 & 0 & - \\
\hline Acid from adonitol & 48 & 0 & 0 & - \\
\hline Acid from L-arabinose & 61 & 0 & 0 & - \\
\hline Arginine dihydrolase & 61 & 0 & 0 & - \\
\hline Catalase production & 61 & 100 & 100 & + \\
\hline Acid from cellobiose & 29 & 0 & 0 & - \\
\hline Chitinase production & 48 & 0 & 0 & - \\
\hline Citrate (Christensen) utilization & 61 & 100 & 100 & + \\
\hline Citrate (Simmons) utilization & 61 & $70^{a}$ & $90^{a}$ & $t^{a}$ \\
\hline Collagenase & 48 & 0 & 0 & - \\
\hline Deoxyribonuclease production & 48 & 0 & 0 & - \\
\hline Acid from dulcitol & 48 & 0 & 0 & - \\
\hline Acid from erythritol & 29 & 0 & 0 & - \\
\hline Esculin hydrolysis & 48 & 0 & 0 & - \\
\hline Acid from D-fructose & 48 & 98 & 98 & + \\
\hline Acid from D-galactose & 48 & 98 & 98 & + \\
\hline Gelatin hydrolysis & 48 & 0 & 0 & - \\
\hline Acid from D-glucose & 61 & 100 & 100 & + \\
\hline Gas from D-glucose & 61 & $49^{a}$ & $90^{a}$ & $++^{a}$ \\
\hline Acid from glycerol & 48 & 90 & 100 & + \\
\hline Acid from glycogen & 48 & 0 & 0 & - \\
\hline Hemolysis on sheep blood agar & 61 & 0 & 0 & - \\
\hline $\mathrm{H}_{2} \mathrm{~S}$ production (Kligler) & 61 & 0 & 0 & - \\
\hline Indole production & 61 & 100 & 100 & + \\
\hline Acid from $m$-inositol & 48 & 0 & 0 & - \\
\hline Acid from inulin & 48 & 0 & 0 & - \\
\hline Growth in $\mathrm{KCN}$ & 48 & 98 & 100 & + \\
\hline Acid from D-lactose & 61 & 0 & 0 & - \\
\hline Lecithinase production & 48 & 0 & 0 & - \\
\hline Lipase (Tween 80 hydrolysis) & 48 & 0 & 0 & - \\
\hline Lysine decarboxylase production & 61 & 0 & 0 & - \\
\hline Utilization of malonate & 61 & 0 & 0 & - \\
\hline Acid from maltose & 61 & 0 & 0 & - \\
\hline Acid from D-mannitol & 61 & 2 & 2 & - \\
\hline Acid from D-mannose & 48 & 100 & 100 & + \\
\hline Acid from melezitose & 48 & 0 & 0 & - \\
\hline Acid from melibiose & 48 & 0 & 0 & - \\
\hline Methyl red $\left(36^{\circ} \mathrm{C}\right)$ & 29 & 100 & 100 & + \\
\hline Motility at $25^{\circ} \mathrm{C}$ & 61 & $87^{a}$ & $89^{a}$ & $t^{a}$ \\
\hline Motility at $36^{\circ} \mathrm{C}$ & 61 & $48^{a}$ & $51^{a}$ & $t^{a}$ \\
\hline Mucate utilization & 29 & 0 & 0 & - \\
\hline Nitrite from nitrate & 48 & 100 & 100 & + \\
\hline ONPG production ${ }^{b}$ & 48 & 2 & & - \\
\hline Ornithine decarboxylase production & 61 & 0 & 0 & - \\
\hline Oxidase production & 61 & 0 & 0 & - \\
\hline Pectate utilization & 29 & 0 & 0 & - \\
\hline Phenylalanine deaminase production & 61 & 100 & 100 & + \\
\hline $\begin{array}{l}\text { Pigment brownish around the colo- } \\
\text { nies in the presence of iron ions, } \\
\text { oxygen, and tyrosine }\end{array}$ & 29 & 100 & 100 & + \\
\hline Acid from raffinose & 48 & 0 & 0 & - \\
\hline Acid from L-rhamnose & 61 & 8 & 8 & - \\
\hline Hydrolysis of salicin & 29 & 0 & 0 & - \\
\hline Acid from sorbitol & 48 & 0 & 0 & - \\
\hline Acid from L-sorbose & 48 & 0 & 0 & - \\
\hline Hydrolysis of starch & 48 & 0 & 0 & - \\
\hline Acid from sucrose & 48 & 8 & 100 & $++^{c}$ \\
\hline Tartrate (Jordan) utilization & 48 & 0 & 0 & - \\
\hline Acid from trehalose & 61 & 0 & 0 & - \\
\hline L-Tyrosine clearing & 13 & 100 & 100 & + \\
\hline Urease production & 61 & 0 & 0 & - \\
\hline Voges-Proskauer reaction & 13 & 0 & 0 & - \\
\hline Acid from $D$-xylose & 61 & 0 & 0 & - \\
\hline
\end{tabular}

${ }^{a}$ Weak reaction.

${ }^{b}$ ONPG, $\alpha$-Nitrophenyl- $\beta$-D-galactopyranoside.

$c$ Delayed reaction. 
TABLE 4. Tests of value in differentiating $P$. friedericiana from other Providencia species

\begin{tabular}{|c|c|c|c|c|c|c|c|c|c|c|c|c|c|c|}
\hline \multirow{3}{*}{ Test } & \multicolumn{2}{|c|}{ P. friedericiana } & \multicolumn{6}{|c|}{ P. alcalifaciens } & \multicolumn{4}{|c|}{ P. stuartii } & \multicolumn{2}{|c|}{ P. rettgeri } \\
\hline & \multirow[b]{2}{*}{$\begin{array}{c}\% \\
\text { Positive }\end{array}$} & \multirow[b]{2}{*}{$\begin{array}{c}\text { Reaction } \\
\text { of strain } \\
1 / 33^{T}\end{array}$} & \multirow[b]{2}{*}{$\begin{array}{c}\% \text { Positive } \\
\text { (reference } \\
4)^{a}\end{array}$} & \multirow{2}{*}{$\begin{array}{c}\% \text { Positive } \\
\text { (reference } \\
8)^{b}\end{array}$} & \multicolumn{4}{|c|}{ Reaction of: } & \multirow{2}{*}{$\begin{array}{c}\text { \% Positive } \\
\text { (reference } \\
4)^{a}\end{array}$} & \multirow{2}{*}{$\begin{array}{l}\% \text { Positive } \\
\text { (reference } \\
8)^{b}\end{array}$} & \multicolumn{2}{|c|}{ Reaction of: } & \multirow{2}{*}{$\begin{array}{c}\% \text { Positive } \\
\text { (reference } \\
4)^{a}\end{array}$} & \multirow{2}{*}{$\begin{array}{c}\% \text { Positive } \\
\text { (reference } \\
8)^{b}\end{array}$} \\
\hline & & & & & $\begin{array}{c}\text { Bio- } \\
\text { group } \\
1 \\
\end{array}$ & $\begin{array}{c}\text { Bio- } \\
\text { group } \\
2 \\
\end{array}$ & $\begin{array}{c}\text { Bio- } \\
\text { group } \\
3 \\
\end{array}$ & $\begin{array}{c}\text { Bio- } \\
\text { group } \\
4\end{array}$ & & & $\begin{array}{c}\text { Bio- } \\
\text { group } \\
5\end{array}$ & $\begin{array}{c}\text { Bio- } \\
\text { group } \\
6\end{array}$ & & \\
\hline $\begin{array}{l}\text { Acetate utiliza- } \\
\text { tion }\end{array}$ & $0 / 0^{c}$ & - & 30 & $27 / 29^{d}$ & & & & & 81 & $84 / 8^{d}$ & & & 59 & $59 / 23^{d}$ \\
\hline $\begin{array}{l}\text { Acid from adoni- } \\
\text { tol }\end{array}$ & $0 / 0$ & - & 94 & $95 / 0.2$ & t & + & - & - & 4 & 4 & - & + & 99 & $81 / 6$ \\
\hline $\begin{array}{l}\text { Citrate (Sim- } \\
\text { mons) }\end{array}$ & $70 / 90^{e}$ & $+e$ & 98 & $98 / 1.3$ & & & & & 93 & $96 / 3$ & & & 96 & $96 / 8$ \\
\hline Gas from glucose & $49 / 90^{e}$ & $t^{e}$ & 85 & $86 / 0.6$ & + & - & + & - & 0 & 0 & - & - & 12 & 12 \\
\hline $\begin{array}{l}\text { Acid from glycer- } \\
\text { ol }\end{array}$ & $90 / 100$ & + & 12 & $11 / 55$ & & & & & 12 & $34 / 66$ & & & 66 & $66 / 33$ \\
\hline $\begin{array}{l}\text { Acid from } m \text {-ino- } \\
\text { sitol }\end{array}$ & $0 / 0$ & - & 1 & 1 & - & - & - & - & 97 & $98 / 3$ & + & + & 93 & $93 / 5$ \\
\hline $\begin{array}{l}\text { Acid from manni- } \\
\text { tol }\end{array}$ & $2 / 2$ & - & 2 & $2 / 0.2$ & & & & & 13 & $13 / 1$ & & & 99 & 89 \\
\hline Motility at $36^{\circ} \mathrm{C}$ & $48 / 51^{e}$ & $+^{e}$ & 96 & $96 / 0.3$ & & & & & 86 & $86 / 3$ & & & 94 & 94 \\
\hline $\begin{array}{l}\text { Acid from su- } \\
\text { crose }\end{array}$ & $8 / 100$ & $+^{f}$ & 13 & $13 / 74$ & & & & & 31 & $26 / 66$ & & & 13 & $13 / 57$ \\
\hline Tartrate (Jordan) & $0 / 0$ & - & 100 & 100 & + & t & + & + & 96 & 96 & & & 96 & 96 \\
\hline $\begin{array}{l}\text { Acid from treha- } \\
\text { lose }\end{array}$ & $0 / 0$ & - & 4 & $4 / 1$ & & & & & 99 & $87 / 6$ & & & 1 & $16 / 1$ \\
\hline $\begin{array}{l}\text { Urease produc- } \\
\text { tion }\end{array}$ & $0 / 0$ & - & $\mathbf{0}$ & 0 & - & - & - & - & 15 & 0 & & & 99 & 100 \\
\hline
\end{tabular}

${ }^{a}$ Percentage of strains positive after 2 days; data from the study of Brenner et al. (4).

${ }^{b}$ Data from the study of Edwards and Ewing (8).

${ }^{c}$ Cumulative percentage of strains positive after 1 to 2 days/cumulative percentage of strains positive after 3 to 7 days.

${ }^{d}$ Percentage of strains positive after 2 days/percentage of strains positive after 3 or more days.

${ }^{e}$ Weak reaction.

$\stackrel{f}{\circ}$ Delayed reaction. 
ence between $P$. alcalifaciens biogroup 3 strains and $P$. friedericiana. However, biogroup 3 strains do not belong to the other groups (e.g., biogroups 1 and 2), as Brenner et al. have shown (4), and all biogroup 4 strains examined have shown the biochemical characteristics of $P$. stuartii. Therefore, some strains that have been described previously as $P$. alcalifaciens may belong to the new species $P$. friedericiana, which shows a clear-cut biochemical profile with less variability.

$P$. friedericiana is distinguished from $P$. stuartii on the basis of its negative reactions for acetate, inositol, Jordan tartrate, and trehalose and its positive reactions for glycerol and sucrose. Negative acetate, adonitol, inositol, mannitol, Jordan tartrate, and urease tests differentiate $P$. friedericiana from $P$. rettgeri.

Guanine-plus-cytosine content. The guanineplus-cytosine contents of the deoxyribonucleic acids of strains $1 / 1$ and $1 / 33^{\mathrm{T}}(\mathrm{T}=$ type strain) were determined spectrophotometrically by thermal denaturation. The ratios obtained were $39 \pm 1.5 \mathrm{~mol} \%$, corresponding well to the values determined previously for the genus Providencia $(4,12)$.

Antimicrobial susceptibility. Eight strains and a total of 18 cultures were tested for susceptibility to amikacin, ampicillin, azlocillin, cefalotin, cefazolin, cefotaxim, cefoxitin, cefuroxim, chloramphenicol, clindamycin, erythromycin, fosfomycin (plus glucose 6-phosphate), fusidic acid, gentamicin, mezlocillin, nitrofurantoin, oxacillin, penicillin $\mathrm{G}$, pipemidic acid, piperacillin, tetracycline, tobramycin, and trimethoprimsulfamethoxazole. All strains were resistant to clindamycin, fusidic acid, penicillin $\mathrm{G}$, and oxacillin and showed intermediate susceptibility to nitrofurantion. Seven strains were resistant to erythromycin, and one showed intermediate susceptibility. Six strains were susceptible to ampicillin, one was resistant, and one showed intermediate susceptibility. Seven strains were susceptible to cephalotin and chloramphenicol, and one was intermediately susceptible. Full susceptibility to all other substances was observed. There was no clear distinction between $P$. friedericiana and the strains of $P$. alcalifaciens and $P$. stuartii tested.

\section{DISCUSSION}

Their growth characteristics, guanine-plus-cytosine contents, and biochemical profiles indicate that the strains isolated from penguins belong to the genus Providencia. The common habitat and the occurrence of the organisms in the intestinal tracts of different penguin species suggest a genetically and phenoytypically homogeneous group. A number of phenotype features show that these bacteria are different from the previously described Providencia species. However, the lack of detail in the description of $P$. alcalifaciens creates some difficulties. Of course, Brenner et al. (4) found that the eight biogroup 3 strains which they studied belonged to a hybridization group that was separate from the strains of biogroups 1 and 2 and suggested that biogroup 3 strains represent a new species. Unfortunately, these authors studied no strains of biogroup 4 because all of the strains presumed to belong to biogroup 4 were typical strains of $P$. stuartii. It is possible that real strains of biogroup 4 are anaerogenic strains of $P$. friedericiana. Therefore, the suggestion of Brenner et al. endorses the proposal to establish $P$. friedericiana as a new species with a circumscribed habitat.

There is some evidence that bacterial taxa are as old as the ecological niches in which they are living $(15,16)$. Therefore, $P$. friedericiana may have existed as a normal inhabitant of the intestines of penguins since the Tertiary period. The habitats of the other Providencia species are not known $(12,13)$; it is possible that these organisms were derived from $P$. friedericiana by acquisition of properties that improved their environmental survival. Greater mobility, utilization of acetate and tartrate, and stronger utilization of citrate may be viewed as adaptions to the outer world. An alternative hypothesis is that $P$. friedericiana descended from $P$. alcalifaciens by loss of the ability to utilize some compounds, regular fermentation of some other carbohydrates, and reduced motility at $36^{\circ} \mathrm{C}$, as it occurs in numerous species and is well adapted to life in its hosts.

The very few biogroup 3 and 4 strains of $P$. alcalifaciens that have been isolated from humans seem to be atypical strains of $P$. friedericiana as indicated by positive tartrate utilization. The other biochemical properties of these biogroups have not been described with sufficient precision.

Description of Providencia friedericiana sp. nov. This closed group of organisms from a welldefined habitat without intimate contact with human beings suggests the establishment of a new independent species within the genus Providencia. Therefore, I propose the name Providencia friedericiana sp. nov. (frie.de.ri.ci.a'na. M.L. adj. friedericiana, derived from the German names Friederike and Friederich [most of the technical work of this study was done by Friederike Heimbach]). Strain 1/33 (= DSM 2620 ) is the type strain of the species.

Motile by peritrichous flagella at $25^{\circ} \mathrm{C}$; motility mostly absent at $36^{\circ} \mathrm{C}$. Not encapsulated. Brownish pigment produced under special conditions. The biochemical properties are shown in 
Table 3. Tests useful for differentiating $P$. friedericiana from other Providencia species are shown in Table 4.

\section{ACKNOWLEDGMENTS}

I thank R. Hammann for determining the base ratio for strain DSM 2620 and Friederike Heimbach for excellent technical assistance.

\section{ADDENDUM IN PROOF}

Recently, Hickman-Brenner et al. (F. W. HickmanBrenner, J. J. Farmer III, A. G. Steigerwalt, and D. J. Brenner, J. Clin. Microbiol. 17:1057-1060, 1983) described Providencia rustigiana as a new species in the family Enterobacteriaceae. It was formerly known as Providencia alcalifaciens biogroup 3. The biochemical properties of the 11 studied strains seem to be very similar to those of $P$. friedericiana.

\section{LITERATURE CITED}

1. Baine, W. B., J. K. Rasheed, J. C. Feeley, G. W. Gorman, and L. E. Casida. 1978. Effect of supplemental L-tyrosine on pigment production in cultures of the Legionnaires' disease bacterium. Curr. Microbiol. 1:93-94.

2. Bauer, A. W., W. M. M. Kirby, J. C. Sherris, and M. Turck. 1966. Antibiotic susceptibility testing by a standardized single disk method. Am. J. Clin. Pathol. 45:493496.

3. Bockemühl, J., and I. Bednarek. 1975. Die Verwendung von LIM (Lysin-Indol-Motilitäts)-Medium zur primären Identifizierung pathogener Darmbakterien. Zentralbl. Bakteriol. Parasitenkd. Infektionskr. Hyg. Abt. 1 Orig. Reihe A 232:259-265.

4. Brenner, D. J., J. J. Farmer III, G. R. Fanning, A. G. Steigerwalt, P. Klykken, H. G. Wathen, F. W. Hickman, and W. H. Ewing. 1978. Deoxyribonucleic acid relatedness of Proteus and Providencia species. Int. J. Syst. Bacteriol. 28:269-282.

5. Buttiaux, R., R. Frenoy, and J. Moriamez. 1954. Les caracteres biochimiques du genre Providencia. Ann. Inst. Pasteur Lille 6:62-79.
6. Cowan, S. T. 1974. Cowan and Steel's manual for the identification of medical bacteria, 2nd ed. Cambridge University Press, Cambridge.

7. Deutsches Institut Für Normung e.V. DIN. 1979. DIN 58940 Methoden zur Empfindlichkeitsprüfung von bakteriellen Krankheitserregern (ausser Mykobakterien) gegen Chemotherapeutika. Deutsches Institut für Normung e.V. DIN, Berlin

8. Edwards, P. R., and W. H. Ewing. 1972. Identification of Enterobacteriaceae, 3rd ed. Burgess Publishing Co., Minneapolis.

9. Forbes, L. 1981. Rapid flagella stain. J. Clin. Microbiol 13:807-809.

10. Gerhardt, P., R. G. E. Murray, R. N. Costilow, E. W Nester, W. A. Wood, N. R. Krieg, and G. B. Philips (ed.) 1981. Manual of methods for general bacteriology. American Society for Microbiology, Washington, D.C.

11. Hallmann, L., and F. Burkhardt. 1974. Klinische Mikrobiologie, 4. Aufl. Thieme, Stuttgart.

12. Lautrop, H. 1974. Genus X. Proteus Hauser 1885, 12, p. 327-330. In R. E. Buchanan and N. E. Gibbons (ed.), Bergey's manual of determinative bacteriology, 8th ed The Williams \& Wilkins Co., Baltimore.

13. Lennette, E. H., A. Balows, W. J. Hausler, Jr., and J. P. Truant (ed.). 1980. Manual of clinical microbiology, 3rd ed. American Society for Microbiology, Washington, D.C.

14. Marmur, J., and P. Doty. 1962. Determination of the base composition of deoxyribonucleic acid from its thermal denaturation temperature. J. Mol. Biol. 5:109-118.

15. Müller, H. E. 1977. Age and evolution of bacteria. Experientia 33:979-984.

16. Roggendorf, M., and H. E. Müller. 1976. Enterobakterien bei Reptilien. Zentralbl. Bakteriol. Parasitenkd. Infektionskr. Hyg. Abt. 1 Orig. Reihe A 236:22-35.

17. Skerman, V. B. D., V. McGowan, and P. H. A. Sneath (ed.). 1980. Approved lists of bacterial names. Int. J. Syst. Bacteriol. 30:225-420.

18. Traub, W. H., and E. A. Raymond. 1970. Modified motility-indole-ornithine- $\mathrm{H}_{2} \mathrm{~S}$ medium (MIOH) for the routine identification of rapid lactose-fermenting Enterobacteriaceae. Zentralbl. Bakteriol. Parasitenkd. Infektionskr. Hyg. Abt. 1 Orig. Reihe A 215:401-403. 